\title{
Education for Sustainable Development in Saudi Arabia: A Critical Discourse Analysis of Media and Government Policy Documents
}

\author{
Shaemaa Essa ${ }^{1 *}\left[\right.$ (]) , Blane Harvey ${ }^{1}$ (1)
}

${ }^{1}$ Department of Integrated Studies in Education, McGill University, Montreal, CANADA

*Corresponding Author: shaemaa.essa@mail.mcgill.ca

Citation: Essa, S., \& Harvey, B. (2022). Education for Sustainable Development in Saudi Arabia: A Critical Discourse Analysis of Media and Government Policy Documents. Interdisciplinary Journal of Environmental and Science Education, $18(2)$, e2266. https://doi.org/10.21601/ijese/11519

\section{ARTICLE INFO}

Received: 22 Nov. 2021

Accepted: 31 Dec. 2021

\begin{abstract}
This qualitative study examines the Kingdom of Saudi Arabia's policy of integrating Education for Sustainable Development (ESD) into the Saudi education system under the country's Vision 2030 sustainable development strategy. The study specifically asks: how is the policy of integrating ESD in the Saudi education system presented in the discourses of the Saudi government policy documents and the written media? The study examines two types of documents, namely official policy documents published by the governmental entities involved in the planning and/or the execution of the ESD integration policy, and newspaper articles collected from the three topranked Saudi newspapers (Arab News, Asharq Al-Awsat, and Al Riyadh). Thematic coding was used to identify themes and sub-themes in the collected documents. In addition, Fairclough's model of Critical Discourse Analysis (CDA) was employed to offer a deeper understanding of whether Saudi Arabia meaningfully aims at integrating sustainable development into its education planning in Vision 2030. Results suggest that Vision 2030 does not consider ESD as a main tool to achieve sustainability and preserve the environment. The analysis reveals that there are very limited discussion of ESD integration in Vision 2030, both in the media coverage as well as the government official documents. Moreover, the CDA of the collected data shows there is a great generalism in the language used in presenting the road map to implementing ESD, and considerable vagueness on the proposed procedures for integrating ESD into the Saudi education system. Consequently, there is a lack of a comprehensive strategic plan with pre-determined steps. The findings of the study suggest that despite statements to the contrary, the Saudi government is not taking the plan of ESD integration into education seriously.
\end{abstract}

Keywords: education for sustinability, document analysis, environmental education, Saudi Arabia

\section{INTRODUCTION AND OVERVIEW}

During the 70th session of the United Nations' General Assembly in September 2015, 195 nations gathered and adopted the UN Sustainable Development Goals (SDGs). The United Nations Educational, Scientific and Cultural Organization (UNESCO) announced that, in demonstrating its active participation, the international community should aim at accomplishing those goals by the year 2030 (UNESCO, 2015). To effectively ensure these goals are met, an emphasis was placed on the full cooperation and commitment of the international community and the participation of its respective states' public sectors (government and education), private sectors (businesses), media, and NGOs.

In December 2015, 196 countries signed and adopted, by consensus, the Paris Agreement on Climate Change. Through the agreement, parties committed themselves to establish local and national policies as a path to achieve a set of longterm goals. These goals include the commitment to limit climate change's impact on the environment by limiting global warming to less than 2 degrees Celsius and aiming to limit warming to less than 1.5 degrees Celsius (Clean Development Mechanism National Designated Authority, n.d.; UN, 2021). Saudi Arabia, as a signatory country to the agreement, has promised to make a great effort to reach an annual avoidance; "up to 130 million tonnes of carbon dioxide $\left(\mathrm{CO}_{2}\right)$ equivalent emissions ... by 2030" (Wagon et al., 2019, p. 5).

Achieving the goals set out in both the SDGs and the Paris Agreement requires a significant investment in educational transformation. The central role that education can play in shaping values, understanding and awareness of environmental and sustainability challenges, and our individual relationship with these challenges is well established (Nevin, 2008; Ozturk, 2008), as is its role as a driver of personal, national and global development (Jong-Wha, 2014). As such, it is essential that global and local policy makers and leaders invest in education systems that have the quality and relevant focus needed to achieve sustainable 
economic development and reduce human-made environmental risks (Jong-Wha, 2014; Nevin, 2008).

Addressing these global climate and sustainability challenges in the Kingdom of Saudi Arabia (KSA) is no different. In order to achieve the objectives of its national 2030 development vision, called Vision 2030, the Saudi government acknowledges the need to examine its the current educational policies and their contribution to the country's economy and environment (Allmnakrah \& Evers, 2020). However, it is not clear how Saudi Arabia, as a signatory state to both the SDGs and the Paris Agreement, will reconcile these aims with the government's national economic development strategies. The Kingdom has made a number of promises to meet its national and international commitments on sustainability and climate change (for which Saudia Arabia is responsible for $4 \%$ of all global emission) (Saiyid, 2021). Nevertheless, it seems that the country has not made a meaningful progress on this issue. According to Braun (2020, para. 4), regardless their rhetoric on sustainability and climate change, the Kingdom has very weak " $\mathrm{CO}_{2}$ reduction targets" and their country's "actions have failed to live up to the rhetoric". Braun (2020, para. 4) adds that the Kingdom continues to block and hinder any dialogue about "fossil fuel subsidy removal that the G20 plans to implement by $2025 . "$

This study seeks to better understand this gap between rhetoric and reality, particularly in relation to Saudi Arabia's integration of sustainable development into its education policies, planning and curriculum through Vision 2030. To do so, we probe the discourse and framing of education for sustainable development in two types of sources: government policy documents and news coverage in three major Saudi print media outlets. We begin by providing an overview of climate and sustainability challenges and responses in Saudi Arabia, focusing in particular on the national Vision 2030 strategy, and the positioning of education for sustainable development within that strategy. Next, we outline the methodological framework and methods used to undertake this analysis - an approach grounded in critical discourse analysis (Fairclough, 2003). We then present the results of our analysis of six policy documents and 27 news articles that were retained in our screening process. Finally, our discussion and conclusions draw insights about Vision 2030 and the wider ESD and sustainability landscape in Saudi Arabia from analysis at the level of the text (what is being said by KSA and national media); the discourse (what is being implied or conveyed through these texts); and the wider social practice (how these two other levels reflect the mindsets and governance that prevail in the country). Understanding these dynamics, we argue, allows us to identify the opportunities and obstacles to meaningful progress on sustainable development - and the use of education as a catalyst for sustainable development - in the country.

\section{Climate Change, Sustainability, and National Development Pathways in Saudi Arabia}

As an arid, oil exporting nation, KSA is deeply connected to both the drivers and the impacts of climate change. Since the oil boom of the1970s, the KSA's carbon dioxide $\left(\mathrm{CO}_{2}\right)$ emissions have been steadily rising at an average annual rate of $5.85 \%$ with $\mathrm{CO}_{2}$ emissions reaching 614.6 million tonnes in
2019 , or approximately $1.9 \%$ of global emissions (Ritchie \& Roser, 2020). On a per capita basis, KSA ranks among the world's highest emitters at 16.99 tonnes of $\mathrm{CO}_{2}$ per capita, compared to a global average of 4.71 tonnes. Understood through a more holistic indicator, KSA's ecological footprint was 5.7 global hectares per person in 2017 (Global Footprint Network, 2020). This high ecological footprint of Saudi Arabia indicates that the high consumption of the natural resources, the low efficiency of using energy and the limited expansion of the country's biocapacity (Saab, 2012). As the world's second largest oil-producer (U.S. Energy Information Administration, 2017), 87 \% of the Saudi economy depends on the petroleum industry which represents approximately $42 \%$ of the country's Gross Domestic Product (Economy of Saudi Arabia, 2020, para. 1). This heavy dependency on petroleum exports suggests that measures of KSA's domestic consumption do not fully capture the country's global contribution to climate and environmental impacts.

While much is made of KSA's contribution to climate impacts through the consumption and export of petroleum, it is also important to note that the country also has significant vulnerabilities to climate impacts. It ranks $72^{\text {nd }}$ globally on the NDGain vulnerability index, where a higher ranking represents low vulnerability. The fact that $98 \%$ of Saudi land is desert and only $1.6 \%$ is available for agriculture poses some of the greatest environmental and sustainability challenges for the country. More specifically, these challenges include desertification, deforestation, and food and water security, not to mention poor waste management, overexploitation of natural resources, and loss of biodiversity (Al-Dosary, 2016; Taher \& Hajjar, 2013). Taher \& Hajjar (2013) argue that these environmental challenges continue to escalate and require an immediate consideration at the Saudi government.

Turning now to KSA's engagement on the global stage on climate and sustainability, Cooke (2019) suggests that the country's performance is quite an embarrassment; with KSA being named one of the worst countries according to the Climate Change Performance Index (https://ccpi.org/). The Climate Action Tracker initiative echoes this assessment of Saudi Arabia's commitments under the Paris Agreement, rating them as "critically insufficient" and noting that "Saudi Arabia has put few climate policies in place, and diversification away from an oil-based economy has been slow" (Climate Action Tracker (Saudi Arabia), 2021, para. 4). Cooke (2019) adds that Saudi Arabia has been among the countries attempting to deny the threat of climate change as well as disrupting any actions to contain it, whether by blocking dialogue in multilateral negotiations, or by repeatedly censoring discussions on fossil fuel subsidies domestically. This obstructionist behaviour is not new for KSA, with Fang and Lerner (2019) arguing that the country has a history of hindering any international efforts to reduce carbon emissions spanning the past 30 years.

\section{Vision 2030}

In the face of these sustainability and diplomatic challenges, in 2016 Saudi Arabia implemented a national strategy for sustainable development, named Vision 2030. The strategy was launched April 25, 2016 under the supervision of Mohamed bin Salman (the current Saudi Crown Prince, 
Defense Minister and Head of the Council of Economic and Developmental Affairs) as a strategic road map to achieve a more sustainable future. This vision was inspired by, and shares the same timeframe as, the UN General Assembly's 2030 Agenda and its Sustainable Development Goals (SDGs). The KSA government describes Vision 2030 on its official website as follows:

Vision 2030 is a bold yet achievable blueprint for an ambitious nation. It expresses our long-term goals and expectations, and it is built upon our country's unique strength and capabilities. It guides our aspiration towards a new phase of development- to create a vibrant society in which all citizens can fulfill their dreams, hopes and ambitions to succeed in a thriving economy (para. 3).

The groundbreaking agenda of Vision 2030 is built on three pillars: a vibrant society, a thriving economy, and an ambitious nation- that draw on the country's intrinsic strengths to help the Kingdom's citizens realize their aspirations (para. 4). Based on these three pillars the vision has set 96 objectives to be achieved by 2030 (Vision, 2030).

This vision aims at reducing the economic dependency on oil returns (Hubbard \& Kelly, 2016) and integrating the 17 SDGs into the state's programs and plans with the partnership of all ministries, sectors (private and public), and organizations (governmental and non-governmental) (Alghamdi, 2017 as cited in Rana \& Alayed, 2018). However, Alshuwaikhat and Mohammed (2017, p. 12) caution that having not only a clear strategic plan but also a "comprehensive and periodic assessments" of performance of these plans remains a very critical step to ensure the achievement of the SDGs.

\section{Education as a Means for Sustainable Development in} Saudi Arabia

The need to create quality educational curricula that promotes care for our planet and addresses the issues of sustainable development is urgent (Gadotti, 2008). We have noted the important link between education and progress on sustainable development goals, a link enshrined in the concept of Education for Sustainable Development (or ESD) and acknowledged in KSA's Vision 2030. Below we briefly outline this concept and its emergence before beginning our analysis of the specific case of ESD in the context of Saudi Arabia.

The term "Environmental Education" (EE) emerged in the 1970s with a focus on raising the awareness of the different types of pollution (Wals \& Benavot, 2017). Its goal was to create a more positive behavior towards the environment, and to mobilize a communal and organizational support for new environmental legislation (Wals \& Benavot, 2017). The concept of "Sustainability Education" (SE) followed in the late twentieth century, offering a wider and more holistic approach than EE. SE targeted societal engagement on issues related to sustainability and sustainable development. It broadens the understanding of the different, yet mutually interacting dimensions of sustainability, including economy, culture, ecology and environment, and aims to build awareness of how our daily actions affect both the planet and future generations. Finally, the contemporary understanding of "Environmental and Sustainability Education" or "Education for Sustainable Development" (ESD) build upon these traditions, but integrates a relational focus on "rethinking humanity's place in the world and global citizenship” (Wals \& Benavot, 2017, p. 406) which engage values and principles to create more sustainable lifestyles. Cartea (2005) concludes that ESD should be considered "a continuation of EE" (p. 292); EE focuses on social learning whereas ESD directs effort to individual as well as social learning (Hume \& Barry, 2015). In the documents under investigation for the purposes of this study, EE and ESD are used interchangeably as synonyms. Thus, for the goal of this paper, we use ESD to refer to both ESD as well as EE.

In terms of the practical integration of ESD into national education systems, guidance from the United Nations Economic Commission for Europe (UNECE) sets out a three phase implementation framework to help countries manage this integration across all levels of the system (UNECE, 2009). The first phase is stocktaking and planning which includes "a review of current policies, legal and operational frameworks, financial mechanisms, and educational activities, and would also include identification of any obstacles or gaps" (UNECE, 2009, p. 23). The second phase is creating and implementing the ESD policy itself. The final phase is the assessment and evaluation of the ESD plan and its implementation (UNECE, 2009; UNESCO, 2008).

According to its First Voluntary National Review on Sustainable Development, delivered to the UN High-Level Political Forum in 2018, Saudi Arabia has always believed in the power of education giving all the needed attention and resources to utilize the education sector as an enabler. Therefore, a "Royal Order was issued to include the SDGs into education curricula" (The Council of Economic and Development Affairs, 2018, p. 23) to enable the achievement of the Saudi 2030 Vision by raising awareness and understanding of the sustainability concepts and issues in the field of education. This aims of integrating ESD into the public education curricula and would involve progressing considerably beyond what is currently offered in public schools.

In a review of environmental education in the $\mathrm{K}-12$ public education system, Al-Dosary (2016) finds that the Saudi public educational system lacks a clear ESD curriculum. Concepts like ecosystems, biodiversity, soil, and water, are present mainly in the early grades-in the science curriculum, without providing any further practical activities to contextualize them (Al-Dosary, 2016). Other topics such as pollution, energy efficiency, and climate change are neither well-discussed nor even simply mentioned (Al-Dosary, 2016). He explains that even where the curriculum does discuss some environmental issues, the tends to be neither be presented in a comprehensive manner nor cover the environmental challenges related, in particular, to the Saudi environment. Al-Dosary concludes that there is no clear ESD integration strategy in the current used curriculum. Al-Dosary's (2016) critical assessment of the current integration of ESD into the Saudi educational curriculum sits at odds with government statements about the country's deep commitment to this aim. 
Table 1. Selected policy documents

\begin{tabular}{|c|c|c|c|}
\hline Document title & Publisher & Date & $\begin{array}{l}\text { Assigned } \\
\text { code }\end{array}$ \\
\hline Education and Vision 2030 & Ministry of Education & $\begin{array}{l}\text { Last modified } \\
23 / 3 / 2019\end{array}$ & $\mathrm{P} 1$ \\
\hline National Transformation Program & Vision 2030 Committee & Updated in 2018 & P2 \\
\hline 1st Voluntary National Review Kingdom of Saudi Arabia & Council of Economic and Development Affairs (CEDA) & 2018 & P3 \\
\hline The National Environmental Strategy & Ministry of Water and Agriculture & 2017 & $\mathrm{P} 4$ \\
\hline Vision 2030 & CEDA & 2016 & P5 \\
\hline $\begin{array}{l}\text { KSA Vision } 2030 \text { Strategic Objectives and Vision } \\
\text { Realization Programs }\end{array}$ & Vision 2030 Committee & n.d. & P6 \\
\hline
\end{tabular}

\section{METHODS}

\section{Methodological Framework}

This study aims to analyse and understand how Saudi Arabia presents its educational goal of integrating ESD into education curricula as part of the state's Vision 2030. It does so by critically examining official policy documents, published by the Saudi government, and news articles featured in the Saudi press that discuss the government's plans of ESD implementation. These two different types of documents were chosen to draw a more comprehensive picture of the actual integration plan set by the Saudi government. On one hand, the policy documents can reveal the actual plans and existing policies to integrate ESD into education. On the other hand, the news coverage can reflect the government's related effort, if any, as presented to the global as well as the local community. More specifically, the analysis in this study addressed the following question: How is the policy of integrating ESD in the Saudi educational system presented in the discourses of the Saudi government policy documents and the written media? In an attempt to answer this question, we looked at these documents for the occurrence of three concepts within the context of education: sustainability, climate change, and sustainable development. These occurrences were then studied in greater depth to understand the framing of education and sustainability in Vision 2030.

We used critical discourse analysis (CDA) as a method to study how the texts under investigation "construct the representations" (Taylor, 2002) of the Saudi Vision 2030 framework and the government's ESD integration plan. In CDA, language is never viewed as a "neutral" entity, but as a carrier of the writer's values, attitudes and assessment and beliefs as well as a reflection of social practices (Fairclough \& Wodak, 1997). This makes CDA an effective approach for examining educational strategy and policy (Rodgers et al., 2016). Khalifeh (2017) also states that CDA is one of the most suitable methods that help in understating and examining the role of media, and newspapers in particular, in shaping the public perception of educational reform and policy. As such, CDA serves as an appropriate method analyse both policy documents and news articles, examining how the language used in these texts reflect both explicit and implicit aims, values, and socio-political dynamics in the Saudi context.

CDA was employed in our analysis to reveal how the selected documents are positioned in relation to the Saudi Vision 2030 agenda and ESD implementation plan. Analysis of these documents followed the methodological steps proposed by Bowen (2009), which involved coding the documents under investigation, then naming themes in order to interpret the content and produce an analysis. We interpreted the collected data using Fairclough's (2003) three-stage model of CDA, which examines discourse at the levels of the text, discourse practice, and wider sociocultural practice. In this study, stage one involved examining the language used in the discourse under investigation. Stage two considered the context in which the texts are produced, and the interpretation perceived by the researcher as an audience. In stage three, the texts were studied in light of the ideology of the Saudi leadership system as an absolute monarchy.

\section{Materials and Data Collection}

As described above, two types of sources were examined through the study: official government documents and news articles. The policy documents were published by KSA governmental entities involved in the planning and/or execution of the ESD integration process, including: The Ministry of Education, the Ministry of Economy and Planning, The Council of Economic and Development Affairs, and the KSA Vision 2030 Committee. Newspaper articles were collected from three top newspapers: Arab News, Asharq AlAwsat, and Al Riyadh Daily. We describe these materials in more detail below.

\section{Policy documents}

Six main official documents, presented in Table 1, published by different Saudi authorities were inspected. The documents were chosen based on their relevance to the subject matter under investigation and on their alignment with Vision 2030 goals as they were published after April 25th, 2016 when the Vision's plans and objectives were first announced.

\section{Newspaper articles}

Newspaper articles were identified as a type of discourse that presents the ESD integration plan in Vision 2030 to public audiences differently from policy documents. As Fairclough (2003) notes, different discourses provide different perspectives and views of the same issue. Exploring news articles helped to capture a wider picture of what the Saudi government was attempting to publicize about their ESD integration plan in Vision 2030 to local, regional and international communities.

The three top-ranked online newspapers in Saudi Arabia (Arab News, Asharq Al-Awsat, and Al Riyadh) were selected for our search of news articles (Top newspapers in Saudi Arabia web ranking, 2019). We also included the Saudi Press Agency, which is considered the official government news agency, as it 
provides press releases to many local and international news agencies, including the three news outlets we selected.

1. Arab News was the first daily English-language newspaper in Saudi Arabia. It was established in 1975 and is published by the Saudi Research \& Publication Company (Arab News, 2020). It is considered the most widely read newspaper in English in Saudi Arabia and the third most widely read in the Gulf region (Arab News is most widely read English daily in the Arab world: Survey, 2015).

2. Al-Riyadh (newspaper) is a pro-governmental newspaper founded in 1965. It is based in, and named after the capital of Saudi Arabia, Riyadh (Al-Riyadh, 2020). Al-Riyadh is an Arabic language newspaper accompanied by an English version (Al Riyadh daily). Although it is published by a private company, Al Yamamah Press, and alleged to be an independent newspaper, it basically reflects the views of the current Saudi royal ruler, King Salman (Saudi Arabia: Media Market Description, 2008).

3. Finally, Asharq Al-Awsat (the Middle East in Arabic) is a "pioneer" regional and international newspaper based in London (Asharq Al-Awsat, 2020). It is the first “pan- Arab" daily newspaper (established in 1978) and is also owned by the Saudi Research and Publishing Company (Asharq Al-Awsat, 2020). It promises its Arab readers around the world an "objective" and "in-depth" coverage and analysis of local Arab and international western events as well (Tatweer Education Holding, n.d.). Yet, it is known for its support to the government and the Royal Family in Saudi Arabia (Fattah, 2005).

Our search strategy is as follows: Searches were conducted in both English and Arabi. English-language searches for news articles were conducted using the ProQuest International News database, which includes newspapers from outside of the USA and Canada. This database includes all the three selected newspapers. It, also, contains archives of Saudi Press Agency dating back to 2009. For the Arabic-language searches, we used the archives of the Arabic version newspapers, namely $\mathrm{Al}-$ Riyadh and Al-Sharq Al-Awsat, available on their websites.

In terms of search parameters, different combinations of search strings were used to identify articles that discuss, or simply mention terms related to education for sustainable development and Vision 2030. In English, the search strings used were:

- "Sustainabl" AND "Saudi Arabia” OR "Saudi" AND "Vision 2030" AND "Education"

- "Saudi Arabia" AND "Education" AND "Climate change"

- "Education" AND "Sustainable development" AND "Saudi Arabia"

- "Sustainabl"” "Education" AND "Saudi" AND "Vision 2030"

- "Environmental Education" AND "Saudi Arabia" OR "Saudi"

In Arabic, the following strings were used:

$$
\begin{aligned}
& \text { ”السعودية ”و “"التعليم البيئي ”و ”رؤية 2030" }
\end{aligned}
$$

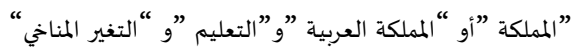

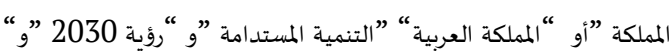

Table 2. ESD integration plan magnitude scale (adapted from Bieler et al., 2017)

\begin{tabular}{|c|c|}
\hline Score & Descriptor \\
\hline 0 & No mention of Education for Sustainable Development \\
\hline 1 & $\begin{array}{l}\text { Very general information about Education for Sustainable } \\
\text { Development or sustainable development in Vision } 2030\end{array}$ \\
\hline 2 & $\begin{array}{l}\text { Mention of limited details about the integration of ESD in } \\
\text { the educational system }\end{array}$ \\
\hline 3 & $\begin{array}{l}\text { Detailed descriptions such as strategic plans or steps } \\
\text { regarding the integration of ESD into the education system } \\
\text { under Vision } 2030\end{array}$ \\
\hline
\end{tabular}

The search was limited to a date range of August 1, 2016, to February 29, 2020. While Vision 2030 was launched on April 25,2016 , August 1st was chosen as a start date parameter to exclude materials simply reporting the launch of the strategy. Search results were then manually screened to exclude duplicates and any article that have not met the inclusion criteria. A total of 27 articles were retained for the analysis. These were all in English. Two Arabic-language articles were identified, but were duplicates of English-language articles, and thus the English versions were retained.

\section{Data Coding}

Two cycles of coding were used in studying all documents under investigation (both policy documents and news articles).

\section{Co-occurrence (first cycle of coding)}

In this cycle we performed a mechanical search to identify co-occurrences of the term 'education' with the terms 'sustainability', 'sustainable development', 'environmental', 'climate change', or 'SDGs'. This mechanical search method was used with both policy documents and news articles. With news articles, we searched using both Arabic and English search terms.

\section{Magnitude (second cycle of coding)}

This type of coding is usually used with data to show "its intensity, frequency, ...presence and evaluative content" (Saldana, 2013, p. 73). For the second coding cycle, we adapted Bieler et al.'s (2017) rating scale on ESD integration (see Table 2) to code all co-occurrences identified in the first cycle. This scale was used to indicate the extent to which there were details of specific plans for integrating ESD into the educational system within Vision 2030 framework.

\section{RESULTS}

\section{Co-Occurrences and Intensity of Engagement}

The number of the co-occurrences of 'education' with terms 'sustainability', 'sustainable development', 'environmental', etc. were very limited in both the news articles and policy documents. In the policy documents only seven instances of co-occurrence were identified, while only fourteen co-occurrences were found in the news articles. The seven co-occurrences in policy documents appeared only in two documents, namely the 1st Voluntary National Review 
Table 3. Number and magnitude of co-occurrences on ESD integration

\begin{tabular}{ccc}
\hline Assigned score & \# of policy documents & \# of news articles \\
\hline 0 & 1 & 0 \\
\hline 1 & 3 & 8 \\
\hline 2 & 3 & 5 \\
\hline 3 & 0 & 1 \\
\hline
\end{tabular}

Table 4. Themes and co-occurrence numbers emerged from the analysis

\begin{tabular}{lcc}
\hline Themes/subthemes & \multicolumn{2}{c}{ Number of co-occurrences } \\
\hline Governmental actions & $\begin{array}{c}\text { Policy } \\
\text { documents }\end{array}$ & $\begin{array}{c}\text { News } \\
\text { articles }\end{array}$ \\
\hline National government policy & 8 & 6 \\
\hline ESD Policy & 4 & 3 \\
\hline $\begin{array}{l}\text { ESD integration case studies } \\
\text { examples }\end{array}$ & 4 & 0 \\
\hline Non-governmental actions & 0 & 3 \\
\hline
\end{tabular}

Kingdom of Saudi Arabia (P3) and The National Environmental Strategy (P4). It seems that the news articles were more engaged in providing some details in relation to the ESD integration plan in Vision 2030. As shown in Table 3, based on the second cycle of coding, three policy documents and news articles gave some limited details about the ESD integration plan. Moreover, only one news article was assigned a magnitude score of 3 , as it provided more elaborate details of how to integrate ESD in classroom curriculum. On the other hand, none of the policy documents reached this level of engagement. ${ }^{1}$

\section{Thematic Analysis}

Once we identified co-occurrences and classified them by magnitude, we organized them thematically. This resulted in two main themes that emerged from the analysis: descriptions of actions taken by the government to integrate ESD into education as a part of Vision 2030, and actions taken by other non-governmental bodies (see Table 4). Within each of these two main themes we looked for sub-themes that would provide insights on the types of strategies and actions being undertaken. Three sub-themes were identified. The first, under governmental actions, was national government policy, which consisted of high-level initiatives and committees created by different governmental bodies to encourage or assist in the implementation of ESD plans in education. The second sub-theme (ESD policy) referred to the discussion of specific applicable strategic steps to integrate ESD into education as part of Vision 2030. For example, as stated in P3, as part of the outcomes section of the environmental strategy is to "Raise environmental awareness throughout: the KSA society, generalize environmental education, innovate in environment and meteorology" (Ministry of Water and Agriculture, 2017, p. 66). The third sub-theme consisted of specific examples and cases of ESD integration policy in private schools or universities. Theme Two compiled discussion of the non-governmental actions initiated by either

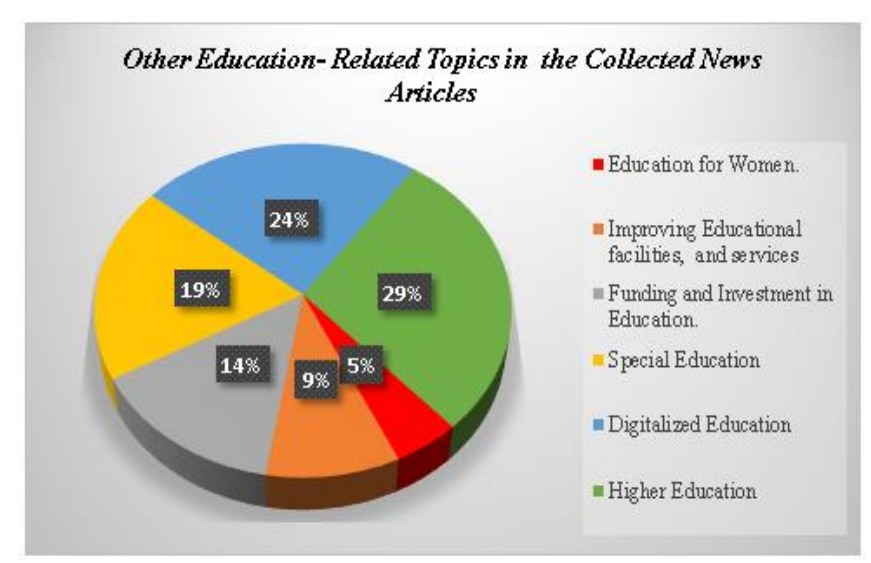

Figure 1. Other education-related topics in in the collected news articles

youth organizations and/or non-governmental organizations (NGO) to promote the implementation of ESD.

As Table 4 illustrates, the most commonly occurring themes and sub-themes in both the news articles and the policy documents dealt with governmental actions; that is to say, announcements by the KSA government's bodies of new policies and committees to carry out the implementation of ESD into education in Vision 2030. Only news articles showed concrete examples or cases of ESD integration in practice. Conversely, only policy documents provided instances that contain guidance on specific steps for integrating ESD into Education. However, news articles and policy documents equally displayed instances of non-governmental actions promoting the integration of ESD into education in Vision 2030.

\section{Education and Sustainability in 2030}

Given the very small number of co-occurrences identified in the analysis, as well as the relatively low magnitude of these co-occurrences, it seems that ESD integration was not the main focus of the discourse of education and sustainability under Vision 2030. This led us to examine what was being discussed under this banner within the identified documents, and how these aligned with the UN's Sustainable Development Goals. What this re-analysis revealed is that there are other topics that appear to be more central to the Vision 2030 focus on education, as illustrated in Figure 1 and Figure 2.

According to these two charts, women's education and improving educational facilities were the two top issues discussed in relation to education in Vision 2030 in news articles. Improving educational facilities also appeared as the second-most-mentioned priority in the policy documents, following education for labour market needs. Additionally, it was obvious through the analysis of the collected policy documents and news articles that - considered through lens of the 17 SDGs, Vision 2030 takes a very unbalanced approach to addressing sustainability. Urban sustainability, diversifying and creating a sustainable economy, creating a sustainable industrialization, promoting sustainable agriculture to create sustainable food availability were the most mentioned issues in the discussion of sustainability in 2030 Vision. In other

\footnotetext{
${ }^{1}$ The full list of identified co-occurrences and their assigned magnitude scores are included in the supplementary materials to this article.
} 


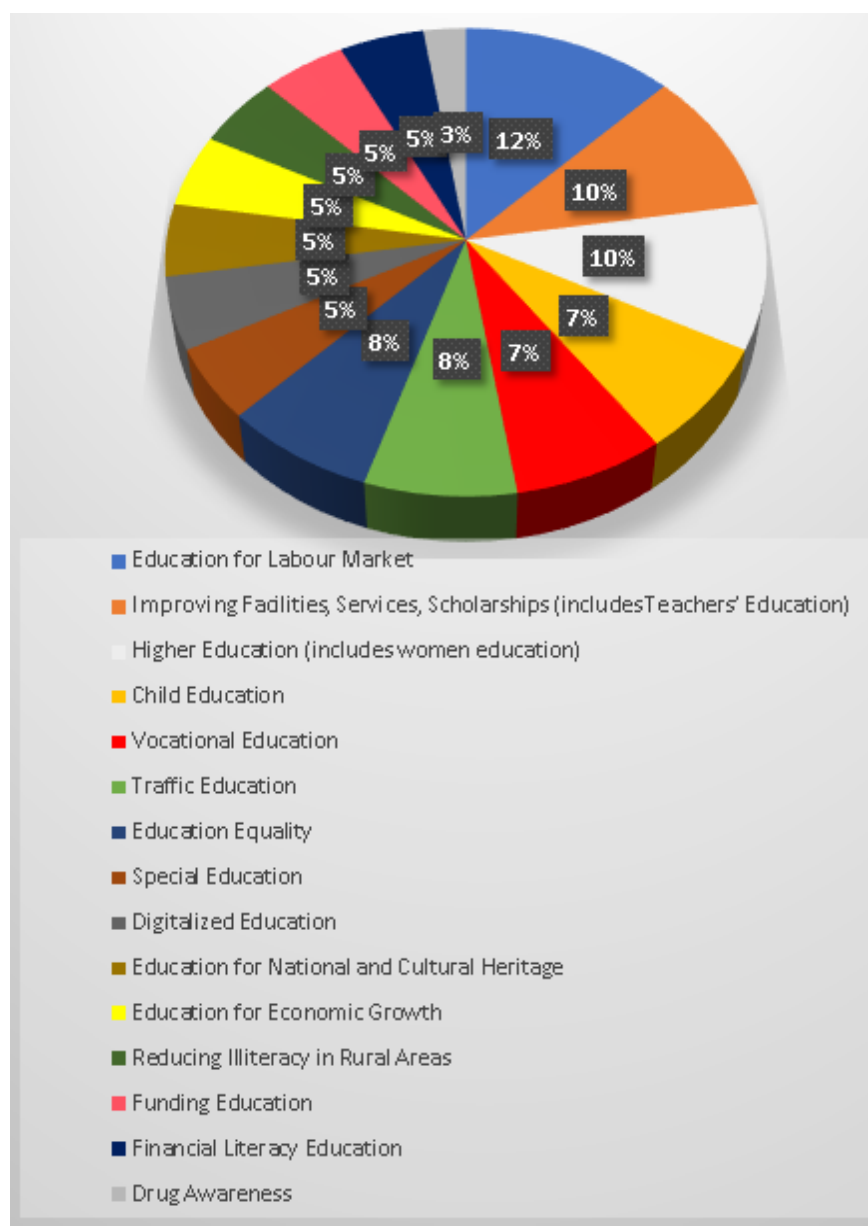

Figure 2. Other education-related topics in policy documents

words, Saudi government has given more attention to these goals SDG 1 (no poverty), SDG 8 (sustainable cities and communities), and SDG 8 (decent work and economic growth). Conversely, responsible consumption and production and climate action, SDG 13 and 14, respectively, were among the least mentioned.

\section{Discourse-Level Analysis of the Retained Texts}

Looking more closely at the content of the retained texts using the lens of Fairclough's three levels of CDA reveals a number of trends. First, we note that the language used in the policy documents as well as the media articles, was very broad and lacking in specificity. For instance, phrases such as 'raising awareness' and 'promoting/ improving people's lives' were mentioned frequently in the documents with reference to ESD, but as our magnitude scoring (noted above) reveals, these were rarely accompanied by concrete proposals on how to do so. Repetition was another major observation, both within the same document and between the different documents. We find the same exact phrases are repeated with the same structure and even with the same wording across many instances.

In addition, the policy documents feature a strong emphasis on bureaucratic responses - again, with limited detail on how these would translate into specific national actions. These technocratic responses, include a royal order being issued (P3), a national committee being set up (P3), a national framework being developed (P3); and creation of a "strategic initiative" of the National Environmental Strategy
(P4). Only one co-occurrence found in the policy documents goes considerably further, describing a series of specific implementation measures to happen in the first three years of Vision 2030.

Looking at the types of discourse deployed through the texts, we find two different appeals to authority in many of the documents. The first is an appeal to the authority of the Saudi monarchy, which was found more frequently in policy documents. This appeared either directly as in "a Royal Order was issued to include the SDGs into education curricula" (P3, p. 3), or indirectly, through the use of many references to royal proclamations, quotes, and actions in the documents. For example:

In order to preserve the unique environmental character of the region, environmental sustainability laws and mechanisms will be developed. Natural resources will be conserved in accordance with the best practices and standards in place globally. 'Crown Prince of the Kingdom of Saudi Arabia Mohammad bin Salman' (P3, p. 5).

and

“King Salman had specifically arrived in Madinah during the holy month to follow up on service delivery and review the implementation of important projects, which were vital for the region's sustainable development." (N9, para. 2).

The second appeal to authority that was frequently mobilized through the documents - most often the new articles - was an appeal to international bodies and treaties. Reference to the United Nations, UNESCO, the Paris Agreement, and the global sustainable development agenda prevailed throughout the analysed documents, more frequently in the news articles than policy documents. For example:

Today, we see the Kingdom's Vision 2030 objectives coincide with UNESCO's mission through the Kingdom's keenness to support educational, cultural, and scientific projects around the world because of its regional and international status, and its roles in strengthening relations between Arab and Islamic countries and the global agenda for sustainable development in the organizations educational. (N3, para. 4).

"Saudi Arabia has adopted the goals of the landmark Paris accord of 2015 that sparked an important change in countries' sustainable development agendas" (N11, para. 11).

"Asheikh stressed that Saudi Arabia and other countries in the region are committed to the fourth objective of the UNESCO 2030 agenda, and to the top priority policies in the Arab regions" (N5, para. 2). 


\section{DISCUSSION}

The focus of this study is to critically analyze some of the most important policy documents as well as written media about ESD integration plan into education in Vision 2030. These two different genres were chosen for the investigation to capture a more comprehensive description of the intended integration plan. The three levels of Fairclough's CDA model, as illustrated in Figure 3, of the collected data showed that at the textual level the language was very general in presenting the roadmap taken to implement an ESD plan which then led to a great vagueness in terms of strategic planning. The details of a 'how-to' procedure to integrate ESD into the Saudi education is minimal, focusing largely on bureaucratic actions such as establishing new frameworks, committees, or steering groups. The absence of a comprehensive strategic plan with pre-determined steps was obvious. This vagueness in communicating the message of ESD integration policy conveys an attitude of unseriousness from the government in carrying out or even simply creating an ESD integration plan. The contrast of this lack of clarity and detail with the government's stated commitment to achieving environmental sustainability is worth reiterating:

By preserving our environment and natural resources, we fulfill our Islamic, human and moral duties. Preservation is also our responsibility to future generations and essential to the quality of our daily lives. We will seek to safeguard our environment by increasing the efficiency of waste management, establishing comprehensive recycling projects, reducing all types of pollution, and fighting desertification. We will also promote the optimal use of our water resources by reducing consumption and utilizing treated and renewable water (CEDA, 2016, p. 23).

The language used also reflects the norm and the culture of Saudi government leadership, which is one of absolute monarchy. There is practical relevance to this reality in terms of ESD. Since the very beginning of the Saudi educational system in the 1950s, education has been strictly centralized and exclusively funded by the state. All schools must use the same a unified curriculum, "methods of instruction, textbooks, evaluation techniques, and educational policy” (Saudi Education System, 2019, para. 4). Thus, any changes or reforms in the educational system must be initiated, funded, and supervised closely by the Ministry of Education (Saudi Education System, 2019). Importantly, even when special committees have been created to support or supervise any planned educational reform, the development has been very slow and uncertain (Al-Essa, 2009, as cited in Tayan, 2017). This strictly hierarchical policy structure places hard limits on the potential for implementing reform - even in line with demands from outside bodies and initiatives. As Allmnakrah \& Evers (2019) note in a study of other educational reform efforts in the KSA, "it appears clear that unfortunately words like 'partnership' and 'cooperation' seem to be an anthem for the reformers" but are not practically applied (p. 31).
Based on Fairclough's (2003) third level - that of sociocultural practice, given that Saudi Arabia is a state under authoritarian leadership, change should always initiate, supervised, and even approved by the government only. Changes are sometimes not meant to be realized, even when they are supported by appeals to external sources of authority such as the United Nations, and thus motions to act on these changes may only be superficial. Based on the analysis here, we conclude that this might well be the case here with plans to integrate ESD into Vision 2030. Given the absence of any comprehensive integration plan, it seems that the Saudi government's stated commitments to concepts such as 'sustainability', 'sustainable future' and ESD in Vision 2030 may again be an "anthem for" the vision (Allmnakrah \& Evers, 2019, p. 31).

\section{CONCLUSIONS}

It is well-established that climate change and environmental degradation pose major threats to development on both the global scale, and nationally in countries like Saudi Arabia. These urgent environmental challenges call on all countries to take action, as reflected in international agreements like the SDGs and the Paris Agreement. Integrating education for sustainable development into education is consistently a major component of these recommended actions.

While it is very true that Saudi Arabia have policy documents that seemingly discuss the concept of sustainability in Vision 2030 in alignment with the UN sustainable developments agenda. Nevertheless, ESD was not a major component of this discussion as it might be expected. The information given on ESD in these documents were limited, and superficial; and the prime focus in these documents were on other- education related topics such as: education for labour market, improving facilities, services and scholarships, higher education (including women's education), child Education, vocational education, and even traffic education. The news articles focused on women's education which could be seen as a response to the criticism made internationally about Saudi Arabia and gender-based discrimination on access to education (Saudi Arabia: Give women equal opportunities to education, 2011; Alsuwaida, 2016).

Also, much of what the Saudi government was presenting in terms of discourse about sustainability and the SDGs is on SDG4, which addressed issues such as improving the efficiency, effectiveness and the quality of education and the teaching and learning processes. (Towards Saudi Arabia's sustainable tomorrow, 2018). According to the Arab News (2020), the Saudi UN envoys have stressed the full commitment of government, as part of Vision 2030, to fully implement the Paris Agreement to preserve the environment by "strengthening measures on climate change" (Saudi Arabia committed to achieving SDGs, para. 4). Although Saudi publicised its interest in sustainability and sustainable development actions and gaols in the analyzed data, it appreared that the government focuses on certain SDGs and ignore others. 
A recent study by Huang et al. (2021) concludes that the Taiwanese government promote ESD initiatives and program as a way to achieve other political gains other than an actual implementation of ESD. The case may be the same here. It seems that what the Saudi government doing is to publicize words more than taking real actions.

Author contributions: All co-authors have involved in all stages of this study while preparing the final version. They all agree with the results and conclusions.

Funding: No external funding is received for this article.

Declaration of interest: The authors declare that they have no competing interests.

Ethics approval and consent to participate: Not applicable.

Availability of data and materials: All data generated or analyzed during this study are available for sharing when appropriate request is directed to corresponding author.

\section{REFERENCES}

Al-Dosary, R. (2016). Waqi' attarbiah fi atta'alim ela'am fil mamlakah [The reality of environmental education in public education in the Kingdom of Saudi Arabia]. Educational Journal of Al-Azhar University, 2(167), 391-420.

Allmnakrah, A., \& Evers, C. (2020). The need for a fundamental shift in the Saudi education system: Implementing the Saudi Arabian economic vision 2030. Research in Education, 106(1), 22-40. https://doi.org/10.1177/0034523719851534

Al-Riyadh. (2020). Wikipedia. https://en.wikipedia.org/wiki/ Al_Riyadh_(newspaper)

Alshuwaikhat, H., \& Mohammed, I. (2017). Sustainability matters in national development visions-evidence from Saudi Arabia's vision for 2030. Sustainability, 9(3), 408. https://doi.org/10.3390/su9030408

Alsuwaida, N. (2016). Women's education in Saudi Arabia. Journal of International Education Research, 12(4), 111-118. https://doi.org/10.19030/jier.v12i4.9796

Arab Forum for Environment and Development. (2019). Environmental education for sustainable development in Arab countries: Annual report. http://www.afedonline.org/en/ reports/details/environmental-education-for-sustainabledevelopment-in-arab-countries

Arab News is most widely read English daily in the Arab world: Survey. (2015). Arabnews. https://www.arabnews.com/ news/779336

Arab News. (2020). https://en.wikipedia.org/wiki/Arab_News

Asharq Al Awsat. (2020). About us https://english.aawsat.com/home/page/1005421

Asharq Al-Awsat. (2020). Wikipedia. https://en.wikipedia.org/ wiki/Asharq_Al-Awsat

Bieler, A., Haluza-Dela, R., Dale, A., \& McKenzie, M. (2017). A national overview of climate change education policy: Policy coherence between subnational climate and education policies in Canada (k-12). Journal of Education for Sustainable Development, 11(2), 63-85. https://doi.org/10. 1177/0973408218754625
Bowen, A. (2009). Document analysis as a qualitative research method. Qualitative Research Journal, 9(2), 27-40. https://doi.org/10.3316/QRJ0902027

Braun, S. (2020). Climate change: Will Saudi Arabia derail G20 climate-led recovery? DW. https://www.dw.com/en/will -saudi-arabia-derail-g20-climate-led-recovery/a55672691

Cartea, P. A. M. (2005). In praise of environmental education. Policy Future in Education, 3(3), 284-295. https://doi.org/ 10.2304/pfie.2005.3.3.6

Clean Development Mechanism Designated National Authority. (n.d.). Paris Agreement. https://www.cdmdna. gov.sa/page/20

Cooke, K. (2019). Saudi Arabia worst performing country battling climate change. Middle East Eye. https://www.middleeasteye.net/opinion/saudi-arabiaworst-performing-country-battling-climate-change

Economy of Saudi Arabia. (2020). Fanack. https://fanack.com/ saudi-arabia/economy

Fairclough, N. (2003). Analysing discourse: Textual analysis for social research. Routledge. https://doi.org/10.4324/97802 03697078

Fairclough, N., \& Wodak. R. (1997). Critical discourse analysis. In T. Van Dijk (Ed.), Discourse as social interaction (pp. 6797). SAGE.

Fattah, H. (2005). Spreading the word: Who's who in the Arab media. The New York Times. https://www.nytimes.com/ 2005/02/06/weekinreview/spreading-the-word-whoswho-in-the-arab-media.html

Global Foorprint Network. (2020). Ecological footprint. wwf.panda.org. https://wwf.panda.org/discover/knowledge _hub/all_publications/ecological_footprint2/

Global Footprint Network. (2020). Home. https://data.footprintnetwork.org/\#/

Huang, Y.-S., Harvey, B., \& Asghar, A. (2021). Bureaucratic exercise? Education for sustainable development in Taiwan through the stories of policy implementers. Environmental Education Research, 27(7), 1099-1114. https://doi.org/10.1080/13504622.2021.1926431

Hubbard, B., \& Kelly, K. (2017). Saudi Arabia's grand plan to move beyond oil: Big goals, bigger hurdles. The New York Times. https:/www.nytimes.com/2017/10/25/world/ middleeast/saudi-arabias-grand-plan-to-move-beyondoil-big-goals-bigger-hurdles.html

Hume, T., \& Barry, J. (2015). Environmental education and education for sustainable development. In J. D. Wrigt (Ed.), International encyclopedia of social and behavioral sciences (pp. 733-739). Elsevier. https://doi.org/10.1016/B978-008-097086-8.91081-X

Jong-Wha, L. (2014). Why we must invest more in education. World Economic Forum. https://www.weforum.org/agenda/ 2014/09/invest-in-education-income-inequality/

Khalifeh, J. (2017). Education policy and newspapers: A critical discourse analysis [Doctoral dissertation, DePaul University]. https://via.library.depaul.edu/soe_etd/132 
McKeown, R. (2009). Education for sustainable development toolkit. UNESCO. https://unesdoc.unesco.org/ark:/48223/ pf0000152453_ara?posInSet=1 \&queryId=af01 be65-80324167-b70e-2fedc45a530e

Nevin, E. (2008). Education and sustainable development. Policy and Practice: A Development Education Review, 6, 4962.

Ozturk, I. (2008). The role of education in economic development: A theoretical perspective. Journal of Rural Development and Administration, XXXIII(1), 39-47. https://doi.org/10.2139/ssrn.1137541

Rana, D., \& Alayed. R. (2018). Green business: Sustainability within Saudi vision 2030. International Journal of Advance Study and Research, 1(9), 2581-5997. https://doi.org/10.5281/zenodo.2532182

Ritchie, H., \& Roser, M. (2020). $\mathrm{CO}_{2}$ and greenhouse emissions. OurWorldInData.org. https://ourworldindata.org/co2/ country/saudi-arabia

Rogers, R., Malancharuvil-Berkes, E., Mosley, M., Hui, D., \& Joseph, G. O. (2005). Critical discourse analysis in education: A review of the literature. Review of Educational Research, 75(3), 365-416. https://doi.org/10.3102/0034654 3075003365

Saab, N. (2012). Arab environment *5 survival options: Ecological footprint of Arab countries. https://www.footprintnetwork. org/content/images/article_uploads/SurvivalOptions_Eng. pdf

Saiyid, A. (2021). Saudi Arabia recommits to 50\% renewable power by 2030. IHSmakit. https://cleanenergynews.ihsmar kit.com/research-analysis/saudi-arabia-recommits-to-50renewable-power-by-2030.html\#: :text=The\%20country's \%20National\%20Renewable\%20Energy,and\%2058.7\%20G W\%20by\%202030

Saldana, J. (2013). The coding manual for qualitative researchers. SAGE.

Saudi Arabia committed to achieving sustainable development goals, says envoy to UN. (2019). The Arab news. https://www.arabnews.com/node/1528436/saudi-arabia

Saudi Arabia. (2020). Wikipedia. https://en.wikipedia.org/ wiki/Saudi_Arabia

Saudi Arabia: Give women equal opportunities to education \& end male guardianship over women. (2011). Equality Now. https://bit.ly/3wMS7SN

Saudi Arabia: Media market description. (2008). World Association of Newspaper. https://web.archive.org/web/20 130921062852/http://www.ihudaif.com/wp-content/uplo ads/2010/01/WORLD-ASSOCIATION-OF-NEWSPAPERS\%E2\%80\%93-WORLD-PRESS-TRENDS-2008.pdf.
Saudi education system. (2018). UKEssays. https://www.ukessays.com/essays/education/the-saudieducation-system-education-essay.php?vref=1

Taher, N., \& Hajjar, B. (2014). Environmental challenges, regulations and institutions in Saudi Arabia. In N. Taher, \& Hajjar, B. (Eds.), Energy and environment in Saudi Arabia: Concerns \& opportunities (pp. 1-26). Springer. https://doi.org/10.1007/978-3-319-02982-5_1

Tatweer Education Holding. (n.d.). About us. https://www.tatweer.sa/en/about-tatweer/?lang=en

Tayan, B. (2017). The Saudi Tatweer education reforms: Implications of neoliberal thought to Saudi education policy. International Education Studies, 10(5), 61-71. https://doi.org/10.5539/ies.v10n5p61

Taylor, S. (2002). Critical discourse analysis in education policy research-to what ends? [Paper presentation]. Australian Association for Research in Education (AARE) Annual Conference, Brisbane. https://www.aare.edu.au/ data/publications/2002/tay02215.pdf

U.S energy information administration: Independent statistics and analysis. (2017). Country analysis brief: Saudi Arabia. https://www.eia.gov/international/content/analy sis/countries_long/Saudi_Arabia/saudi_arabia.pdf

United Nations (UN). (2021). Key aspect of the Paris agreement. https://unfccc.int/process-and-meetings/the-parisagreement/the-paris-agreement/key-aspects-of-theparis-agreement

United Nations Economic Commission for Europe (UNECE). (2009). The UNECE strategy for education for sustainable development. https://sustainabledevelopment.un.org/con tent/documents/798ece5.pdf

United Nations Educational, Scientific and Cultural Organization (UNESCO). (2015). UNESCO and sustainable development goals. https://en.unesco.org/sustainabledeve lopmentgoals

Wagon, D., Carey, E., \& Cooke, D. (2019). Policy pathways to meet Saudi Arabia's contribution to the Paris agreement. KAPSARC Analysis. https://doi.org/10.30573/KS--2018DP49

Wals, A. E. J., \& Benavot, A. (2017). Can we meet the sustainability challenges? The role of education and lifelong learning. Eurapean Journal of Education, 52(4), 404413. https://doi.org/10.1111/ejed.12250 


\section{APPENDIX A}

\section{The Collected Policy Documents, Their Full Citations, and Assigned Codes}

Table A1. Citation of the collected policy documents

\begin{tabular}{|c|c|c|}
\hline Document title & Assigned code & Citation \\
\hline Education and Vision 2030 & P1 & $\begin{array}{l}\text { Ministry of Education. (2019). Education and Vision } 2030 . \\
\text { https://www.moe.gov.sa/en/Pages/vision2030.aspx }\end{array}$ \\
\hline $\begin{array}{l}\text { National Transformation } \\
\text { Program }\end{array}$ & P2 & $\begin{array}{l}\text { Vision } 2030 \text { Committee. (2018). National Transformation Program. } \\
\text { http://www.arabia-saudita.it/files/pages/2014/05/ntp_en.pdf }\end{array}$ \\
\hline $\begin{array}{l}\text { First Voluntary National Review } \\
\text { Kingdom of Saudi Arabia } \\
\end{array}$ & P3 & $\begin{array}{l}\text { The Council of Economic and Development Affairs. (2018). First Voluntary National } \\
\text { Review Kingdom of Saudi Arabia. https://bit.ly/3hjYNzs }\end{array}$ \\
\hline $\begin{array}{l}\text { The National Environmental } \\
\text { Strategy }\end{array}$ & $\mathrm{P} 4$ & $\begin{array}{l}\text { Ministry of Water and Agriculture. (2017). The National Environmental Strategy. } \\
\text { https://rb.gy/u07u4m }\end{array}$ \\
\hline Vision 2030 & P5 & $\begin{array}{l}\text { The Council of Economic and Development Affairs (CEDA). (2016). Vision } 2030 . \\
\text { https://www.vision2030.gov.sa/media/rc0b5oy1/saudi_vision203.pdf }\end{array}$ \\
\hline $\begin{array}{l}\text { KSA Vision } 2030 \text { Strategic } \\
\text { Objectives and Vision } \\
\text { Realization Programs }\end{array}$ & P6 & $\begin{array}{l}\text { Vision } 2030 \text { Committee. (2021). KSA Vision } 2030 \text { Strategic Objectives and Visio Realization } \\
\text { Programs. https://bit.ly/2DcYIyM }\end{array}$ \\
\hline
\end{tabular}




\section{APPENDIX B}

\section{Collected Articles, Their Coding, and Full Citations}

Table A2. Collected articles, full citations, and number of co-occurrences

\begin{tabular}{|c|c|c|}
\hline Article title and citation & AC & NCO \\
\hline Custodian of the two holy mosques chairs cabinet's session. (2018, December 4). Al Riyadh. https://bit.ly/3gPpDC9 & N1 & 0 \\
\hline UNESCO NGO Global Forum to be hosted in Saudi Arabia by MiSK. (2017, April 12)._Al Riyadh. https://bit.ly/35PsvZu & N2 & 2 \\
\hline $\begin{array}{l}\text { Saudi Arabian delegation holds UNESCO reception in Paris. (2019, November 14). Arab News. } \\
\text { https://www.arabnews.com/node/1584216/saudi-arabia }\end{array}$ & N3 & 1 \\
\hline $\begin{array}{l}\text { Vision } 2030 \text { will take Saudi Arabia into the future, standing on the foundations of the past. (2017, September 23). Arab News. } \\
\text { https://www.arabnews.com/node/1165901/saudi-arabia }\end{array}$ & N4 & 0 \\
\hline $\begin{array}{l}\text { We seek to improve quality of teaching; Saudi education minister tells UNESCO meeting. (2019, November 14). ArabNews. } \\
\text { https://www.arabnews.com/node/1583821/saudi-arabia }\end{array}$ & N5 & 0 \\
\hline $\begin{array}{l}\text { Saudi Arabia determined to meet development goals Vision 2030, UN SDGs. (2018, October 18). Arab News. } \\
\text { https://www.arabnews.com/node/1692721 }\end{array}$ & N6 & 0 \\
\hline $\begin{array}{l}\text { MiSK Global Forum to explore youth entrepreneurship, innovation. (2016, November 14). Arab News. } \\
\text { https://www.arabnews.com/node/1010416/saudi-arabia }\end{array}$ & N7 & 1 \\
\hline $\begin{array}{l}\text { Campaign launched against plastic pollution in Saudi Arabia. (2018, November 6). Arab News. } \\
\text { https://www.arabnews.com/node/1405981/saudi-arabia }\end{array}$ & N8 & 1 \\
\hline Big education push for Madinah. (2016, June 24). Arab News. https://www.arabnews.com/node/944251/saudi-arabia & N9 & 1 \\
\hline $\begin{array}{l}\text { Awareness drive to update Saudi students over water scarcity. (2018, August 31). Arab News. } \\
\text { https://www.arabnews.com/node/1364871/saudi-arabia }\end{array}$ & N10 & 2 \\
\hline $\begin{array}{l}\text { UNESCO forum concludes with an eye on sustainable development. (2017, May 5). Arab News. } \\
\text { https://www.arabnews.com/node/1094676/saudi-arabia }\end{array}$ & N11 & 3 \\
\hline $\begin{array}{l}\text { JN sustainable goals. (2017, May 29). Arab News. } \\
\text { /saudi-arabia }\end{array}$ & N12 & 0 \\
\hline $\begin{array}{l}\text { Vision 2030’s alignment with UN goals bodes well for future. (2018, October 18). Arab News. } \\
\text { https://www.arabnews.com/node/1389701 }\end{array}$ & N13 & 1 \\
\hline $\begin{array}{l}\text { Saudi girl scouts attend 24th US jamboree. (2019, July 31). Arab News. } \\
\text { https://www.arabnews.com/node/1533706/corporate-news }\end{array}$ & N14 & 1 \\
\hline $\begin{array}{l}\text { Saudi Arabia committed to achieving sustainable development goals, says envoy to UN. (2019, July 21). } \\
\text { https://www.arabnews.com/node/1528436/saudi-arabia }\end{array}$ & N15 & 0 \\
\hline $\begin{array}{l}\text { Saudi Arabia 'meets key goals in sustainable development'. (2018, April 15). Arab News. } \\
\text { https://www.arabnews.com/node/1285346/saudi-arabia }\end{array}$ & N16 & 0 \\
\hline KSA's first national review of sustainable goals. (2018, July 14). Arab News. https://www.arabnews.com/node/1338971/ & N17 & 0 \\
\hline $\begin{array}{l}\text { Saudi Arabia’s Misk partners with UN on youth empowerment. (2018, September 26). Arab News. } \\
\text { https://www.arabnews.com/node/1378091/saudi-arabia }\end{array}$ & N18 & 1 \\
\hline $\begin{array}{l}\text { A Saudi school with top marks for sustainability. (2019, April 04). Arab News. } \\
\text { https://www.arabnews.com/node/1477426/saudi-arabia }\end{array}$ & N19 & 3 \\
\hline $\begin{array}{l}\text { Saudi Arabia: Good quality education is core for achieving sustainable development. (2017, October 11). AlSharq Al-Awsat. } \\
\text { https://bit.ly/3gR36VR }\end{array}$ & N 20 & 1 \\
\hline Custodian of the two holy mosques chairs cabinet’s session. (2019, November 19). Saudi Press Agency. https://bit.ly/2TSpOUp & N21 & 1 \\
\hline $\begin{array}{l}\text { Significance of sustainability and sustainable development goals (SDGs) in the Kingdom of Saudi Arabia. (2018, July 13). } \\
\text { Saudi Press Agency. https://bit.ly/3qkia16 }\end{array}$ & N 22 & 0 \\
\hline Saudi Press: KSA’s vision 2030 in education. (2019, August 1). Saudi Press Agency. https://bit.ly/3j70Ol7 & N 23 & 0 \\
\hline Crown Prince addresses the UN General Assembly 3 New York. (2016, September 21). Saudi Press Agency. https://bit.ly/3xQCZUm & $\mathrm{N} 24$ & 0 \\
\hline Saudi Press: Saudi Arabia and sustainable development goals 2030. (2020, February 19). Saudi Press Agency. https://bit.ly/2UtfFOd & $\mathrm{N} 25$ & 1 \\
\hline $\begin{array}{l}\text { Kingdom of Saudi Arabia’s address at Economic and Social Council Forum. (2017, May 28). Saudi Press Agency. } \\
\text { https://bit.ly/3zSvSwy }\end{array}$ & N 26 & 0 \\
\hline & & 0 \\
\hline
\end{tabular}

Note: AC-Assigned code; NCO-Number of co-occurences 


\section{APPENDIX C}

\section{The Identified Instances, and the Assigned Engagement Score in Policy Documents and News Articles}

Table A3. Identified instances (bold) in policy documents and the integration plan scores

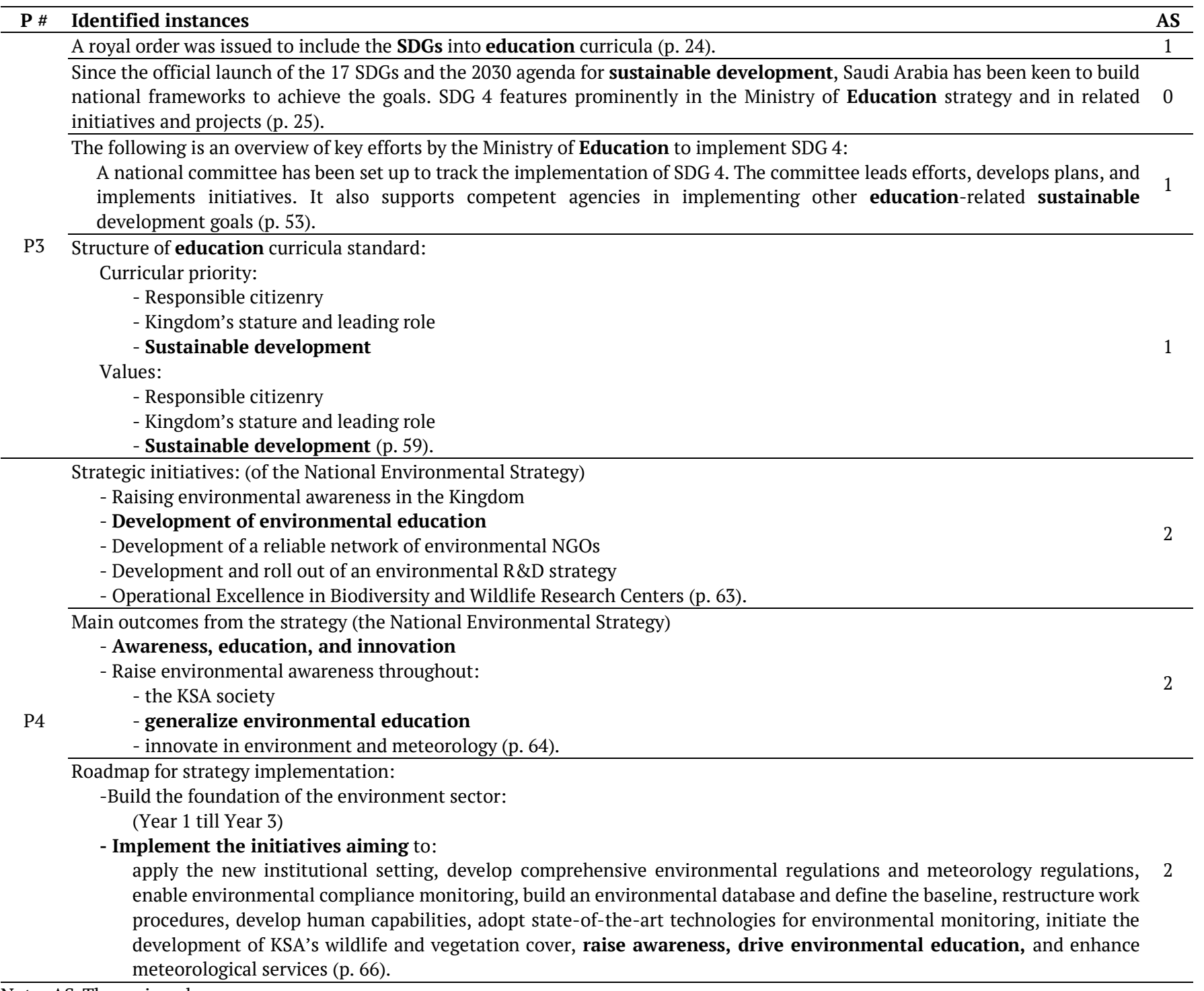




\section{APPENDIX D}

Table A4. Identified instances (bold) in news articles and the integration plan scores

N\# Identified instances

Through keynote speakers, panel discussions, and breakout sessions; the forum will focus on skills and knowledge necessary to prepare young people to live in globalized societies, youth volunteering at local and international level, youth, media,

$\mathrm{N} 2$ and new technologies: enabling critical thinking and skills for young people's active participation, social networks: are they an asset or risk, education for sustainable development provided by youth organizations, including climate change, protection and conservation of cultural heritage: youth engagement in the protection and conservation of tangible and intangible cultural heritage. Today, we see the Kingdom's Vision 2030 objectives coincide with UNESCO's mission through the Kingdom's keenness to support educational, cultural and scientific projects around the world because of its regional and international status, and its roles in strengthening relations between Arab and Islamic countries and the global agenda for sustainable development in the organization's educational, cultural and scientific fields, Al-Asheikh said in his speech

N7 The two-day forum will focus on entrepreneurship and innovation issues covering 16 areas including education, leadership and planning, human development, sustainable development, PR, and media.

MiSK Global Forum (MGF, 2016), an initiative to empower the Arab youth to become global citizens and to lead the way for the

N8 sustainable development of the Kingdom will open here on Tuesday. Al-Humaidan said: "Jeddah University accords a great deal of attention to environmental education as a promoter of quality of life."

N9 Minister of Education Ahmed Al-Issa said King Salman had specifically arrived in Madinah during the holy month to follow up on service delivery and review the implementation of important projects, which were vital for the region's sustainable development. The NWC signed a Memorandum of Understanding (MoU) with Tatweer for planning an awareness campaign and educational

N10 program to create a water conservation culture among Saudis. Al-Zughaibi said the partnership will succeed in achieving aims and objectives of this initiative. "There will be an educational program for preventing counter-productive water habits," he added. Addressing forum participants, Ahmad bin Muhammad Al-Essa, minister of education, said that Saudi schools and universities have made direct initiatives that made a difference in supporting the educational process, while depending on individual efforts filled with ambition to achieve a bright future for the present and future generations. Al-Essa noted the positive role of these initiatives that coincide with the ministry's plans and policies that focus on issues that are of interest to the society such as the environment, water

N11 resources, desertification, and sustainable development. He said the environment of education is adequate to research many of the issues that are of concern to the international community. He expressed the ministry's readiness to cooperate with NGOs in seeking solutions to the issues related to environment and sustainable development within the framework of the Kingdom's efforts in that regard.

Additionally, the Kingdom has always focused on the development of education, so a royal order was issued to bring the SDGs into

N13 education curricula. Work is in progress toward this end, led by the Ministry of Education, in partnership with public and private stakeholders.

N14 We are pleased to see contingents from Saudi Arabia, the GCC, and around the world participating in the jamboree, and for the support of Alwaleed Philanthropies to engage young people in education for peace and sustainable development.

The Saudi-UN partnership aims to reach and mobilize about 50 million young people around the world in support of the sustainable development goals (SDG), via a series of meetings and forums as part of the UN's Strategy for Youth.

N18 The UN's SDG program is a set of targets for future development, ranging from the elimination of hunger and poverty, through education and gender equality, to action on climate change and energy. It coincides with Saudi Arabia's own Vision 2030 strategy in many respects.

From solar panels to recycling water, a Saudi school is instilling vital sustainability practices in its students from a young age. uses the approach of an "integrated education for sustainability, As such, we've established a student-led committee that's empowered to implement sustainability strategies, supported by a ringfenced budget that students themselves are responsible for using."

N19 arlier this year, a group of five Year 11 students came up with an innovative proposal to create sustainable energy sources for BISR. Their entry was chosen, as part of the Zayed Sustainability Prize, in the top 18 out of 2,101 worldwide entries.

There are in fact several sustainability projects rather than just one, as the students are working on several fronts including recycling, energy, water and biodiversity

N20 Ghunaim said that Saudi Arabia pays great attention to education and the provision of good quality of education for all as a basis for improving people's lives and achieving sustainable development.

Minister of Media, Turki bin Abdullah Al-Shabanah, said in a statement to the Saudi Press Agency that the Cabinet pointed to the Kingdom's affirmation at the meeting of the United Nations Educational, Scientific and Cultural Organization (UNESCO) in Paris, of

$\mathrm{N} 21$ its commitment with other countries in the region on the agenda of 2030 UNESCO, through the fourth goal of sustainable development in education, ...

Saudi Cabinet affirmed yesterday the importance of achieving the sustainable development goals 2030 for a prosperous present

N25 and bright future for next generations, reviewing Saudi Arabia's providing of solutions in housing programs, education, and 1 healthcare.

Note: Only instances with score 1 or higher are included in this table 